\title{
New Clinical Anatomical Interpretation of COVID-19 Pandemic Infection
}

\author{
Nueva Interpretación Anatómica y Clínica de la Infección Pandémica COVID-19
}

Shorok Al Dorazi ${ }^{1} \&$ Waseem Al Talalwah ${ }^{2}$

AL DORAZI, S. \& AL TALALWAH, W. New clinical anatomical interpretation of COVID-19 pandemic infection. Int. J. Morphol., 39(2):635-637, 2021.

SUMMARY: Sever acute respiratory syndrome SARS-CoV-2 which is coronavirus disease-2019. It is transmitted by droplet transmission and other methods such aerosols transmission and faecal-oral transmission. The clinical features of Sever acute respiratory syndrome SARS-CoV-2 are fever, cough, dyspnea and gastrointestinal symptoms which present based on affected organ. The current study is anatomical study and provide interpretation of transmission and clinical features as well as the clinical investigation. Further, current study explains complication of coronavirus disease-2019. With explanation of COVID-19 which includes spread clinical features and investigations as well as the consequences by using anatomical clarification result in the intensification of understanding infection and provide high quality in teaching and medical services in future. Therefore, the new disease is a start to learn basic and clinical skills to encourage scientist and physician to improve medical education.

KEY WORD: Sever acute respiratory syndrome SARS-CoV-2; Coronavirus; Fever; Cough; Dyspnea; Gastrointestinal; Anatomy; Medical Education.

\section{INTRODUCTION}

Sever acute respiratory syndrome SARS-CoV-2 is RNA virus belong to Corona virus derivative from crown historically as group of viruses has been assumed to be transmitted from animal to human. It is also known as coronavirus disease-2019 (COVID-19) Since the person has COVID-19 infection (Myth busters) (World Health Organization, 2019). It is mainly transmitted by contact and droplet transmission either direct or indirect contact. The droplet varies in size from 5 to 10 micrometers transmitted from person's secretion such as coughs, sneezes, chat or sings. Further it can be transmitted by micro droplet which is less than 5 micrometer referred as aerosols transmission. As the micro droplet circulate in air considering long distance and time referred as airborne transmission (World Health Organization, 2014; Liu et al., 2020). However, there is another proposed of covid19 transmission through faecaloral transmission (Wang et al., 2020a; Wu et al., 2020) due to Angiotensin-converting enzyme 2 (ACE2) found to be in the gastrointestinal system (Harmer et al., 2002). According to clinical features, the spread of COVID-19 may be possible through contact, droplet, airborne and feco-oral transmissions require anatomical interpretation.
Anatomical interpretation. The COVID-19 is abbreviation of corona virus disease stared in 2019 in Wuhan, china to be announced by World Health Organization (WHO) on march as pandemic over 106 countries. As the COVID-19 passes from infected person to healthy person, it enters the upper respiratory airway through the nasal and oral cavity terminating into pharynx. The pharynx includes anatomically three parts nasopharynx, oropharynx and laryngopharynx (Standring, 2005). Therefore, the diagnosis of COVID-19 is through taken sample from pharynx either by nasal or oral cavities, or both. The first question has been raised over twenty years which one is more accurate nasopharyngeal or oropharyngeal swab. Anatomically, the person breaths from nose usually and mouth occasionally therefore the virus penetrate and replicate in the mucosa of the nasopharynx and oropharynx respectively. This lead to have difference in taking the sample by nasopharyngeal or oropharyngeal swab which is documented by recent research study (Wang et al., 2020b). While, the newborn baby breath through nose (Standring). Therefore, the nasopharyngeal swab may be the most proper method for taken the sample. The complication of nasopharyngeal procedure is swab fracture which

\footnotetext{
${ }^{1}$ Directorate of Prevention and Control of Healthcare Associated Infection, Eastern Province, MOH, P.O. Box 411, Saihat 31972, Saudi Arabia.

${ }^{2}$ Department of Basic Medical Sciences, College of Medicine, King Saud bin Abdulaziz University for Health Sciences, P.O. Box 3660, Riyadh 11481, Saudi Arabia.
} 
considered as a foreign body that result in obstruction or infection of lower respiratory airway (Azar et al., 2020) or the nasal roof penetration (Miller et al., 2020) leading to meningitis or either temporally or permanent Anosmia (loss of smell) due to olfactory nerve injury.

In fact, loss of smell is also one of clinical feature of COVID-19 infection which can be due the damage of nasal epithelium tissue involving smell receptors Further, the loss of taste is also known of hypogeusia which is one of clinical manifestations of COVID-19 that can be explained by viral binding to ACE2 in tongue epithelial cells (Butowt \& von Bartheld, 2020; Bilinska et al., 2020; Bryche et al.; Xu et $a l ., 2020)$. The recovery of smell or taste is variable in time duration among population due to the size and depth of damage as well as the healing process depending on underlining of genetic, race, chronic disease. Etc. (Butowt \& von Bartheld; Bilinska et al.; Bryche et al.; von Bartheld et al., 2020). The smell and taste recovery indicating intact of olfactory nerve and the taste cranial nerves (corda tympani branch of facial, glossopharyngeal and vague nerve) respectively (Standring).

Furthermore, the eye can be another way of COVID19 transmission as the infected person's droplets contaminate the surfaces and the non-infected person contact the contaminated surfaces then touches his eye by his contaminated hands (World Health Organization, 2014; Liu et al.). According to anatomical pathway, the eye has nasolacrimal duct in which the lacrimal glands's secretion passes through this channel into inferior nasal meatus of the nasal cavity. As the nasal cavity communicates with nasopharynx, the COVID-19 transmission can be possible. On the other hand, the infected person tears has no COVID19 virus this may due to several reasons are: gravity, anatomical orientation of nasolacrimal duct as well as histological characteristics of its nasal opening includes mucosal fold known as plica lacrimalis working as a valve (known as valve of Hasner) to prevent backward of secretion to lacrimal duct (Standring).

According to recent research studies, rectal swap is positive and the live virus detected in stool (Hindson, 2020) indicating the possibility of feco-oral transmission between people using public toilet. Usually, the COVID-19 patient present with diarrhea in which the gastrointestinal epithelium includes ACE receptor in enterocyte which absorb intestinal fluid. Dysfunction of enterocyte leads to diarrhea due to failure of absorption in ilium and colon (Gui et al., 2017). Therefore, COVID-19 patient must isolated in room with non-sharing toilet. Also, the physician should consider rectal swab for patient who has history of contact and diarrhea in case of negative result of nasopharyngeal or and oropharyngeal swab.
Distribution of ACE2 receptor in small intestine, heart, venous endothelial, and kidney tissues (Hamming et al., 2004), the Sever Acute Respiratory syndrome SARSCoV-2 virus attack the cell which also assumed in COVID19 (Hoffmann et al., 2020). The question does virus harvest the clinical features of lung directly by invading to cell through ACE receptor and replicate as it has been assumed that COVID-19 transmit from upper to lower respiratory tract? Therefore, how the COVID-19 virus produce the cardiac clinical feature by invading of virus to the pericardium. Anatomically, it is difficult to understand the pathogenesis of virus based only on direct invasion and replication locally unless there is systemic effects that can escalate the mortality rate rather than locally. As the blood vessels include ACE2 receptor, the entire body organs are possible to be endanger of COVID-19 virus such as Thrombosis (clots formation) may result in dysfunction of organ's tissues leading to have more complication. Therefore, the explanation of COVID-19 spread using anatomical clarification will increase understanding the infection and provide high quality in teaching and medical services in future.

\section{ACKNOWLEDGMENT}

I would like to thank the people providing more challenges and difficult circumstances to correlate COVID19 with anatomical explanation providing humble work

AL DORAZI, S. \& AL TALALWAH, W. Nueva interpretación anatómica y clínica de la infección pandémica COVID-19. Int. J. Morphol., 39(2):635-637, 2021.

RESUMEN: El síndrome respiratorio agudo grave (SARS CoV-2) es una enfermedad por coronavirus-2019. Se transmite por transmisión de gotitas y otros métodos como la transmisión por aerosoles y la transmisión fecal-oral. Las características clínicas del síndrome respiratorio agudo severo SARS-CoV-2 son fiebre, tos, disnea y síntomas gastrointestinales y se presentan según el órgano afectado. El reporte actual es un estudio anatómico y proporciona una interpretación de la transmisión y las características clínicas, así como la investigación clínica. Además, el estudio explica la complicación de la enfermedad por COVID-19, que incluye las características clínicas y las investigaciones difundidas, así como las consecuencias. Mediante la aclaración anatómica, se profundiza la comprensión de la infección y se proporciona una alta calidad en la enseñanza y los servicios médicos en el futuro. Por lo tanto, la nueva enfermedad es un comienzo para aprender habilidades básicas y clínicas para alentar a los científicos y médicos a mejorar la educación médica.

PALABRA CLAVE: Síndrome respiratorio agudo severo SARS-CoV-2; Coronavirus; Fiebre; Tos; Disnea; Gastrointestinal; Anatomía; Educación médica. 


\section{REFERENCES}

Azar, A.; Wessell, D. E.; Janus, J. R. \& Simon, L. V. Fractured aluminum nasopharyngeal swab during drive-through testing for COVID-19: radiographic detection of a retained foreign body. Skeletal Radiol., 49(11):1873-7, 2020.

Bilinska, K.; Jakubowska, P.; von Bartheld, C. S. \& Butowt, R. Expression of the SARS-CoV-2 entry Proteins, ACE2 and TMPRSS2, in cells of the olfactory epithelium: identification of cell types and trends with age. ACS Chem. Neurosci., 2020. DOI: https://www.doi.org/10.1021/ acschemneuro.0c00210

Bryche, B.; St Albin, A.; Murri, S.; Lacôte, S.; Pulido, C.; Gouilh, M. A.; Lesellier, S.; Servat, A.; Wasniewski, M.; Picard-Meyer, E.; et al. Massive transient damage of the olfactory epithelium associated with infection of sustentacular cells by SARS-CoV-2 in golden Syrian hamsters. Brain Behav. Immun., 89:579-86, 2020.

Butowt, R. \& von Bartheld, C. S. Anosmia in COVID-19: underlying mechanisms and assessment of an olfactory route to brain infection. Neuroscientist, 1073858420956905, 2020

Gui, M.; Song, W.; Zhou, H.; Xu, J.; Chen, S.; Xiang, Y. \& Wang, X. Cryoelectron microscopy structures of the SARS-CoV spike glycoprotein reveal a prerequisite conformational state for receptor binding. Cell Res., 27(1):119-29, 2017

Hamming, I.; Timens, W.; Bulthuis, M. L. C.; Lely, A. T.; Navis, G. J. \& van Goor, H. Tissue distribution of ACE2 protein, the functional receptor for SARS coronavirus. A first step in understanding SARS pathogenesis. $J$. Pathol., 203(2):631-7, 2004.

Harmer, D.; Gilbert, M.; Borman, R. \& Clark, K. L. Quantitative mRNA expression profiling of ACE 2, a novel homologue of angiotensin converting enzyme. FEBS Lett., 532(1-2):107-10, 2002.

Hindson, J. COVID-19: faecal-oral transmission? Nat. Rev. Gastroenterol. Hepatol., 17(5):259, 2020.

Hoffmann, M.; Kleine-Weber, H.; Schroeder, S.; Krüger, N.; Herrler, T.; Erichsen, S.; Schiergens, T. S.; Herrler, G.; Wu, N. H.; Nitsche, A.; et al. SARS-CoV-2 cell entry depends on ACE2 and TMPRSS2 and is blocked by a clinically proven protease inhibitor. Cell, 181(2):271-280.e8, 2020.

Liu, J.; Liao, X.; Qian, S.; Yuan, J.; Wang, F.; Liu, Y.; Wang, Z.; Wang, F. S.; Liu, L. \& Zhang, Z. Community transmission of severe acute respiratory syndrome coronavirus 2, Shenzhen, China, 2020. Emerg. Infect. Dis., 26(6):1320-3, 2020

Miller, M.; Carlson, K.; Dowdall, J.; Barnes, C. \& Pate, S. Endoscopic removal of fractured 3D-printed nasopharyngeal swabs from the olfactory cleft during COVID-19. Grad. Med. Educ. Res. J., 2(1):12, 2020. Available from: https://digitalcommons.unmc.edu/cgi/ viewcontent.cgi?article $=1103 \&$ context $=$ gmerj

Standring, S. Gray's Anatomy. 39 $9^{\text {th }}$ ed. London, Elsevier, Churchill Livingstone, 2005. pp.687.

von Bartheld, C. S.; Hagen, M. M. \& Butowt, R. Prevalence of chemosensory dysfunction in COVID-19 patients: a systematic review and meta-analysis reveals significant ethnic differences. ACS Chem. Neurosci., 11(19):2944$61,2020$.

Wang, W.; Xu, Y.; Gao, R.; Lu, R.; Han, K.; Wu, G. \& Tan, W. Detection of SARS-CoV-2 in different types of clinical specimens. JAMA, 323(18): 1843-4, 2020a.

Wang, X.; Tan, L.; Wang, X.; Liu, W.; Lu, Y.; Cheng, L. \& Sun, Z. Comparison of nasopharyngeal and oropharyngeal swabs for SARS-CoV-2 detection in 353 patients received tests with both specimens simultaneously. Int. J. Infect. Dis., 94:107-9, 2020b.

World Health Organization (WHO). Infection Prevention and Control of Epidemic-and Pandemic-prone Acute Respiratory Infections in Health Care. WHO Guidelines. Geneva, World Health Organization, 2014. Available from: https://apps.who.int/iris/bitstream/handle/10665/112656/ 9789241507134_eng.pdf;jsessionid=41AA684FB64571 CE8D8A453 C4F2B2096?sequence $=1$
World Health Organization (WHO). Myth Busters. Geneva, World Health Organization, 2019.

Wu, Y.; Guo, C.; Tang, L.; Hong, Z.; Zhou, J.; Dong, X.; Yin, H.; Xiao, Q.; Tang, Y.; Qu, X.; et al. Prolonged presence of SARS-CoV-2 viral RNA in faecal samples. Lancet Gastroenterol. Hepatol., 5(5):434-5, 2020.

Xu, H.; Zhong, L.; Deng, J.; Peng, J.; Dan, H.; Zeng, X.; Li, T. \& Chen, Q. High expression of ACE2 receptor of 2019-nCoV on the epithelial cells of oral mucosa. Int. J. Oral Sci., 12(1):8, 2020.

\section{Corresponding author}

Dr. Waseem Al Talalwah

King Saud bin Abdulaziz University for Health Sciences, Riyadh

Department of Basic Medical Sciences

College of Medicine

PO Box 3660, Riyadh 11481

Mail Code: 3127

KINGDOM OF SAUDI ARABIA

\section{E-mail:waltalalwah@gmail.com altalalwahw@ksau-hs.edu.sa}

Received: 14-03-2020

Accepted: 26-10-2021 